\title{
Pemasaran di Perguruan Tinggi
}

\section{Sugeng Listyo Prabowo}

Dosen Fakultas Tarbiyah Universitas Islam Negeri (UIN) Malang

\begin{abstract}
Abstrak
Higher education (university) as non profit institution service as well as another institution extremely need marketing. In this competitive era and required highly independency, the existence of customer is necessary. For this reason, management in university have to prove and build image in society that his institution able to fulfill the need and the hope of the society.

Marketing in higher education mostly understood as selling and promotion were as marketing is more widely than about of two terminology above mention. Misunderstanding of marketing as usually happen university became "uncomfortable" to use the word marketing in university, because marketing in university is social institution that move in the field of education, that in one hand university have to develop social mission, but in the other hand university have to get the student suit to the condition of capacity, because basically the essence of university is the existence of the student that will be educated and developed whether in cognitive, affective, as well as psychomotor domain.
\end{abstract}

Ulul Albab, Vol. 6 No. 1,2005 


\section{A. Pendahuluan}

Kemandirian merupakan salah satu tema besar dalam berbagai kehidupan, termasuk dalam dunia pendidikan. Peningkatan otonomi pendidikan melalui program Manajemen Berbasis Sekolah, penyelenggaraan Perguruan Tinggi (PT) dengan menggunakan sistem Badan Hukum Milik Negara (BHMN), wacana tentang Badan Hukum Pendidikan (BHP) merupakan upaya-upaya pemerintah yang dilakukan untuk meningkatkan kemandirian lembaga pendidikan seperti yang selama ini telah dialami oleh lembaga-lembaga pendidikan swasta.

Disisi lain, kemandirian tersebut pada kenyataannya harus berhadapan dengan kuatnya iklim persaingan, sehingga pada akhirnya meningkatkan nilai tawar bagi customer terhadap lembaga pendidikan. Kondisi tersebut tidak hanya terjadi pada lembaga-lembaga bisnis, tetapi juga pada lembaga-lembaga non bisnis seperti lembaga pendidikan, rumah sakit, lembaga pelayanan masyarakat bahkan lembagalembaga keagamaan.

Dalam dunia PT persaingan justru dipertajam dengan menurunnya jumlah calon mahasiswa yang akan memasuki dunia PT. Jumlah calon mahasiswa secara keseluruhan yang mendaftar di PT pada tahun-tahun belakangan ini mengalami penurunan sekitar 15\%.' Data yang lebih kongkrit dapat dilihat pada panitia pusat UMPTN, UI Jakarta 1997 yang menunjukkan penurunan jumlah calon mahasiswa antara tahun 1989-1997 seperti terlihat pada tabel berikut

Tabel 1. Kecenderungan Turunnya Minat Masuk PT 1989 - 1997

\begin{tabular}{|c|c|c|c|}
\hline Tahun & Daya Tampung & Pendaftar & $\begin{array}{c}\text { Rasio Daya Tampung } \\
\text { dan Pendaftar }\end{array}$ \\
\hline 1989 & 97.172 & 906.240 & $10.7 \%$ \\
1990 & 75.998 & 931.507 & $8.1 \%$ \\
1991 & 64.826 & 937.982 & $6.9 \%$ \\
1992 & 61.303 & 989.871 & $6.1 \%$ \\
\hline Tahun & Daya Tampung & Pendaftar & Rasio Daya Tampung \\
\hline 1993 & 60.667 & 917.872 & $6.6 \%$ \\
1994 & 60.803 & 900.286 & $6.7 \%$ \\
1995 & 60.411 & 809.153 & $7.4 \%$ \\
1996 & 64.525 & 876.084 & $7.3 \%$ \\
1997 & 63.520 & 798.289 & $7.9 \%$ \\
\hline
\end{tabular}

Ulul Albab, Vol. 6 No. 1, 2005 
Calon mahasiswa menjadi sangat penting dalam hal ini karena calon mahasiswa merupakan sumber finansial utama pada PT, baik itu PTN, BHMN maupun PTS, dan finansial merupakan salah satu tolak ukur dalam melihat organisasi PT yang sehat ${ }^{3}$. Meskipun PT bukan lembaga profit namun dalam kegiatannya sehari-hari PT tetap memerlukan dana. Kebutuhan dana tersebut selain digunakan untuk operasioanl sehari-hari dalam organisasi PT juga diperlukan untuk melakukan pengembangan PT.

Mendasarkan pada perkembangan tersebut itulah, PT sudah selayaknya mempertimbangkan prinsip-prinsip pemasaran seperti yang selama ini dilakukan oleh lembaga-lembaga profit. Seperti yang dikatakan Morris dalam Kriegbaum bahwa tidak ada organisasi, baik itu organisasi bisnis maupun non bisnis yang dapat terlepas dari kegiatan pemasaran. Organisasi tersebut dapat memilih apakah melakukan pemasaran untuk kebaikan organisasi atau meninggalkannya dengan resiko memburuknya organisasi ${ }^{4}$.

Pada dasarnya pemasaran digunakan untuk mempengaruhi seseorang dengan cara yang persuasif karena terjadinya banyak pilihan. Walaupun dalam melakukan pilihan secara psikologis calon mahasiswa juga tergantung pada kondisi personal yaitu kognisi yang merupakan kualitas dan kuantitas pengetahuan yang dimiliki personal tersebut, motif juga sikap, tetapi juga dipengaruhi oleh hal-hal yang berasal dari luar diri personal tersebut yaitu image yang didapat dari informasi yang dilakukan oleh lembaga ${ }^{5}$. Itulah sebabnya melakukan pemasaran juga berarti membangun citra (image) kepada pelanggan yang menjadi sasaran pemasaran.

\section{B. Perguruan Tinggi Sebagai Lembaga Jasa}

Banyak penulis yang berbeda tinjauan tentang pengklasifikasian antara organisasi laba dengan organisasi nir laba. Kenyataan ini diungkapkan oleh Kotler \& Andreasen yang dicuplik dari pendapat beberapa ahli. Pertama pembedaan yang didasarkan pada sumber dana yang mengklasifikasikan organisasi kedalam organisasi yang dihidupi oleh 1) laba, 2) pendapatan pemeritah (pajak, dana sumbangan, pinjaman, dll) dan 3) donasi sukarela kedua pembedaan yang mendasarkan pada sumber dukungan finansial dan besarnya kontrol politik terhadap organisasi tersebut. Ketiga adalah mendasarkan pada dua ciri pokok yaitu donatif atau komersial dan mutual atau enterpreneurial. Sedangkan yang 
keempat adalah mendasarkan pada status istimewa nir laba yaitu, merupakan "barang publik", yang menyatakan bahwa nirlaba memberikan jasa seperti kesehatan, pendidikan dan riset dasar yang tidak disubsidi oleh pemerintah, dan "jaminan kualitas" yang relatif lebih sulit dipertanggungjawabkan mutunya bagi konsumen seperti dalam pelayanan kesehatan dan pendidikan ${ }^{6}$.

Sedangkan Stanton mengatakan bahwa jasa adalah, kegiatan yang dapat diidentifikasi secara tersendiri, yang pada hakekatnya bersifat tak teraba, yang merupakan pemenuhan kebutuhan, dan tidak harus terikat pada penjualan produk atau jasa lain ${ }^{7}$. Untuk menghasilkan jasa mungkin perlu atau mungkin pula tidak diperlukan penggunaan benda nyata. Akan tetapi, sekalipun penggunaan benda itu perlu, namun tidak ada pemindahan hak milik atas benda tersebut. Berdasarkan definisi tersebut PT dapat digolongkan kedalam lembaga jasa, karena pendidikan memiliki sifat-sifat yang terdapat dalam jasa. Lembaga jasa terdiri dari berbagai golongan.

1. Lembaga jasa pemerintah meliputi, departemen tenaga kerja, rumah sakit, layanan militer, polisi dan pemadam kebakaran, kantor pos dan sekolah.

2. Lembaga swasta nir-laba meliputi, museum, masjid, gereja, numah sakit, universitas.

3. Lembaga jasa dengan laba meliputi, penerbangan, bank, hotel, perusahaan asuransi, konsultan manajemen, konsultan hukum, praktek-praktek medis, bioskop ${ }^{8}$.

Produk PT yang sepenuhnya adalah jasa kependidikan tinggi yang terdiri atas jasa kurikuler, jasa penelitian, jasa pengabdian pada masyarakat, jasa administrasi dan jasa ekstrakurikuler ${ }^{9}$. Jika dirinci lebih lanjut, Jasa Kurikuler meliputi antara lain, kurikulum, silabus, rancangan mutu perkuliahan, satuan materi sajian, penyajian materi, evaluasi, praktikum dan pembimbingan. Jasa Penelitian pada pokoknya terdiri dari pembimbingan tentang penelitian, perencanaan, pelaksanaan, dan penyediaan berbagai fasilitas. Hasil penelitian kadang-kadang juga berupa barang yang dapat langsung dipakai atau diperbanyak di pabrik untuk dipasarkan, misalnya model suatu mesin. Namun pada umumnya di PT, penelitian adalah jasa. Jasa Pengabdian pada Masyarakat, meliputi kegiatan-kegiatan untuk membantu (melayani) masyarakat umum, terutama masyarakat yang ekonominya lemah atau pendidikannya masih rendah, dengan menerapkan ilmui-ilmu dan keterampilan yang merupakan Jasa Kependidikan dan Jasa Penelitian. Jasa 
Administrasi meliputi administrasi akademik dan umum. Jasa Ekstrakurikuler meliputi semua kegiatan pelayanan terhadap mahasiswa baik yang langsung mendukung Jasa Kurikuler, Jasa Penelitian dan Jasa Pengabdian pada Masyarakat maupun yang tak langsung, seperti pengembangan minat mahasiswa, pembinaan kesejahteraan minat mahasiswa, dan pembimbingan hubungan dengan dunia kerja.

Melalui proses produksi dan penyajian kelima jasa itu, jasa kependidikan tinggi ditanamkan serta dibudayakan dalam diri dan kehidupan mahasiswa selama masa studi, sehingga kemampuan serta keterampilan akademik maupun profesional terus bertumbuh dalam diri mahasiswa. Pada jenjang Diploma dan S1 (undergraduate) Jasa Kurikuler merupakan bagian terbesar dari jasa kependidikan tinggi, sedangkan pada jenjang Pascasarjana Jasa Penelitian memiliki porsi yang semakin membesar. Dengan penanaman dan pembudayaan itu, juga bantuan serta dorongan faktor-faktor lain mahasiswa berhasil lulus ${ }^{10}$.

Kelima jasa itu pada dasarnya merupakan suatu kebulatan dalam arti keterpaduan untuk membentuk jasa kependidikan tinggi. Kebulatan dan keterpaduan itu dapat dilihat pada gambar 1 :

Gambar 1: Jasa Perguruan Tinggi

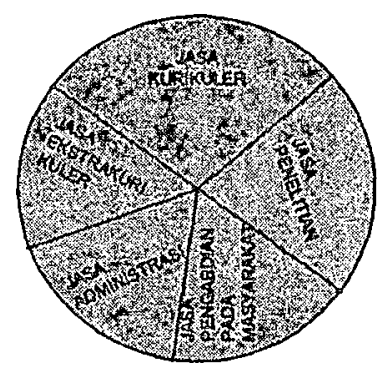

Organisasi nir-laba berjumlah sampai ribuan dan melakukan sejumlah besar kegiatan. Stanton menggolongkan organisasi nir-laba berdasarkan tipe-tipenya: 1) Pendidikan meliputi akademi dan universitas, 2) kebudayaan, 3) keagamaan, 4) amal dan kemanusiaan, 5) tujuan sosial, 6) sosial, 7) perawatan kesehatan, dan 8) politik". Yang dimaksud organisasi nir-laba adalah organisasi yang tidak mementingkan laba sebagai tujuan utamanya. Tetapi bukan berarti organisasi tersebut tidak membutuhkan dana. Dalam organisasi nir-laba termasuk didalamnya adalah PT, membutuhkan 4 hal yaitu perencanaan, pemasaran, sumber daya 
manusia, dan uang ${ }^{12}$. Sumber keuangan antara organisasi nir-laba berbeda-beda. Organisasi bisnis mendapatkan yang dari penjualan, organisasi pemerintah mendapatkan uang dari pajak, sedangkan organisasi non-profit mendapatkan uang dari "pelanggannya".

Dana pada organisasi-organisasi nir-laba biasa didapatkan dari "pelanggan" pada organisasi tersebut, dalam PT pelanggan ini dapat berbentuk mahasiswa, alumni, donatur, agen-agen baik pemerintah maupun swasta. Oleh karena itulah PT melakukan kampanye pengiklanan dan kegiatan promosi untuk menghentikan gerak turun masuknya mahasiswa, yang berarti juga akan menghentikan penurunan dana yang dapat dikumpulkan lembaga pendidikan tersebut ${ }^{13}$. Walaupun lembaga pendidikan tersebut mendapatkan dana dari masuknya mahasiswa baru dan dari berbagai sumber, tetapi bukan berarti dana menjadi tujuan utama dari lembaga pendidikan tersebut. Dana yang didapat dari mahasiswa akan dikembalikan lagi kepada mahasiswa dalam bentuk lain misalnya, untuk biaya operasional lembaga ataupun untuk pengembangan lembaga pendidikan tersebut.

Seperti yang dikemukakan oleh Drucker seringkali dalam definisi organisasi nir-laba uang/ dana jarang disebut-sebut, walaupun demikian para pimpinan lembaga nir-laba yang memiliki reputasi baik menyatakan bahwa mereka akan dapat menyelesaikan banyak masalah dan pengembangan jikalau memiliki banyak uang ${ }^{14}$. Disamping itu pemasaran berfungsi untuk mengkomunikasikan lembaga dengan pihak luar PT, dengan terjalinnya komunikasi yang baik, maka masyarakat akan selalu mengetahui bagaimana kondisi PT yang bersangkutan, dan PT juga akan mengetahui selera atau kebutuhan apa yang sedang berkembang di masyarakat ${ }^{15}$.

Umumnya, organisasi nir-laba merasa tidak "enak" dengan pemasaran. Bagi kebanyakan organisasi ini, pemasaran terbatas pada suatu bentuk promosi, misalnya pengiklanan atau penjualan secara perorangan. Dalam banyak hal, orang yang bergerak dalam organisasi-organisasi nir-laba condong bersikap negatif terhadap pemasaran. Mereka cepat berpikir bahwa program pemasaran adalah hina dan menunjukkan selera yang rendah. Malahan mereka merasa bahwa mempraktekan pemasaran dalam organisasi mereka adalah berlawanan dengan ukuran-ukuran etika.

PT agaknya menghadapi dilema yang sama. Pada satu pihak mereka umumnya tidak menyadari apa sebenarnya makna pemasaran itu, atau mungkin 
malahan bersifat negatif terhadapnya. Sebaliknya, pada pihak lain organisasi ini benar-benar sangat membutuhkan program pemasaran yang efektif. Sekarang dengan berpedoman pendapat yang terakhir ini bahwa pemasaran diperlukan untuk kesehatan organisasi (organization health), maka marilah kita membahas pembangunan program pemasaran bagi organisasi nir-laba ${ }^{16}$.

\section{Konsep Pelanggan pada Perguruan Tinggi}

Pendidikan telah didefinisikan sebagai penyedia jasa. Jasa yang diberikan termasuk biaya pendidikan, penilaian dan bimbingan bagi siswa, orang tua mereka dan para pendukung. Para pelanggan merupakan kelompok yang beragam sehingga perlu untuk didefinisikan. Jika kualitas adalah tentang cara untuk memenuhi kebutuhan dan keinginan pelanggan, penting kiranya memperjelas siapa sebenarnya yang membutuhkan dan menginginkan dan harus dipenuhi kepuasannya.

Terminologi customer umumnya digunakan dalam dunia bisnis, yang merujuk pada seseorang atau kelompok yang membeli suatu produk dari sumber yang spesifik $^{17}$. Pada lembaga profesi istilah pelanggan memiliki sebutan yang berbedabeda. Pada lembaga konsultan biasa menyebut pelanggan dengan istilah "klien", pada lembaga perbankan menyebut dengan istilah "nasabah", pada rumah sakit dengan istilah "pasien", pada organisasi keagamaan dengan istilah "jamaah". Walaupun tidak sama persis antara makna pelanggan pada jenis lembaga tersebut di atas namun dalam beberapa hal memiliki kesamaan esensi.

Dalam konsep Manajemen Mutu, konsep pelanggan adalah proses yang akan dilakukan selanjutnya (the next process is our customer) sehingga yang dimaksud pelanggan tersebut dapat dilihat pada gambar 2:

Gambar 2: Konsep Pelanggan dalam Manajemen Mutu

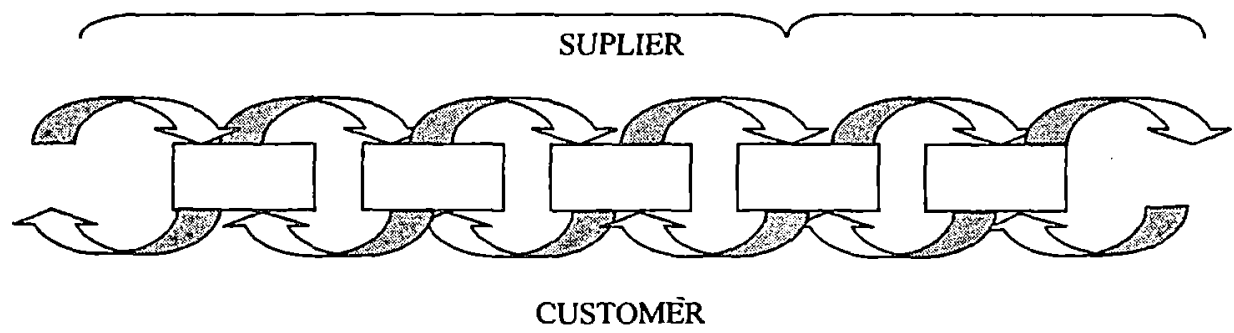

Hubungan mutu suplier-customer

Ulul Albab, Vol. 6 No. 1, 2005 
Beberapa ahli pendidikan menilai kata "pelanggan" dalam konteks pendidikan, berbau komersial sehingga tidak dapat diterapkan dalam pendidikan. Dalam Perguruan Tinggi istilah pelanggan lebih sering disebut dengan kata stakeholders. Kata "stakeholders" dalam konotasinya mengarah pada yang memiliki kepentingan, sehingga dinilai lebih cocok. Namun demikian, hakiki sebenarnya adalah sama, yaitu mengarah pada pelanggan jasa pendidikan.

Dalam hal ini secara khusus, dibedakan antara stakeholders, yaitu mereka yang memperoleh warisan dari layanan pendidikan, dan stakeholders bagi mereka yang membayar untuk pendidikan, seperti orang tua, gubernur, pegawai atau pemerintah. Pengertian pelanggan dibedakan menjadi Pelanggan Primer, yaitu mereka yang langsung menerima jasa pendidikan tersebut, dan Pelanggan Sekunder adalah yang mendukung pendidikan seperti orang tua, pemerintah dan sebagainya. Selain itu, ada "pelanggan tersier", yaitu mereka yang secara tidak langsung mempunyai andil, tetapi memegang peranan penting dalam pendidikan (selaku pemegang kebijakan), seperti pegawai, masyarakat dan sebagainya. Pulungan menggambarkan hubungan antara pelanggan tersebut di atas seperti terlihat pada gambar 3:

Gambar 3: Hubungan antara Pelanggan dengan PT dalam Proses Jasa Pendidikan ${ }^{18}$

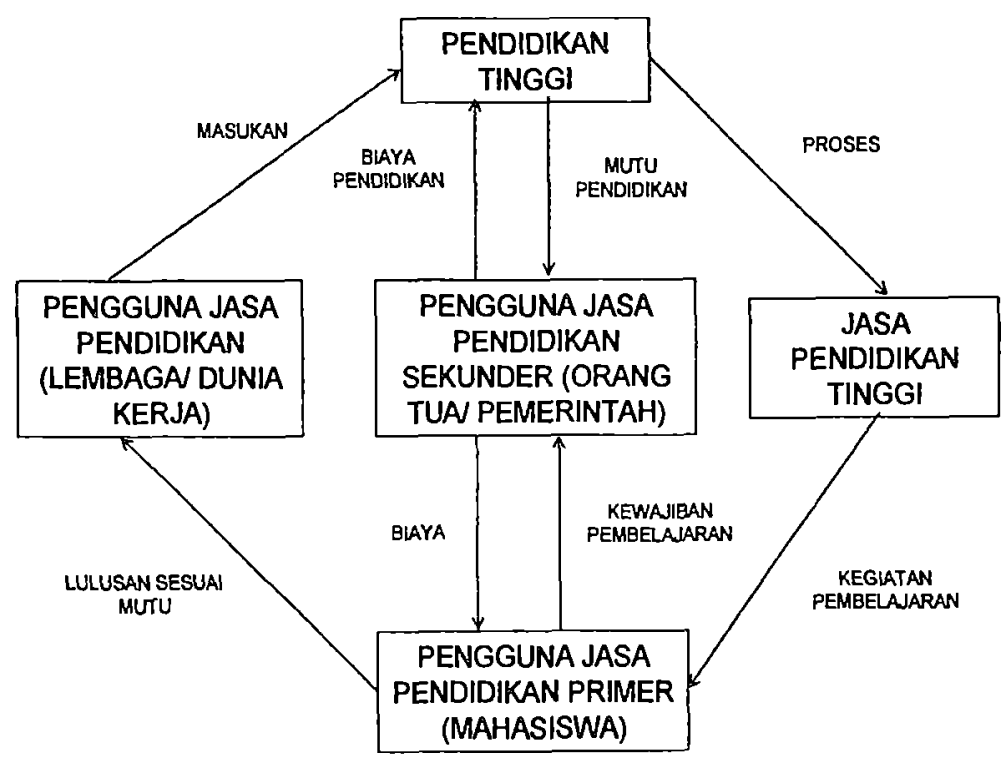

Ulul Albab, Vol. 6 No. 1, 2005 
Dalam konteks yang berbeda Unal mengkategorikan stakeholders PT menjadi stakeholders suppliers dan stakeholders customers. Stakeholders suppliers meliputi keluarga, sekolah menengah atas, program D2, sektor bisnis yang seringkali mengirimkan tenaga kerjanya untuk mengikuti pendidikan dan pelatihan di PT, sedangkan stakeholders customers meliputi kantor pemerintah, lembaga bisnis, keluarga dan para siswa. Hubungan antara berbagai stakeholders tersebut seperti terlihat pada gambar 4:

Gambar 4: Pelanggan Suplayers dan Pelanggan Customers pada PT ${ }^{19}$

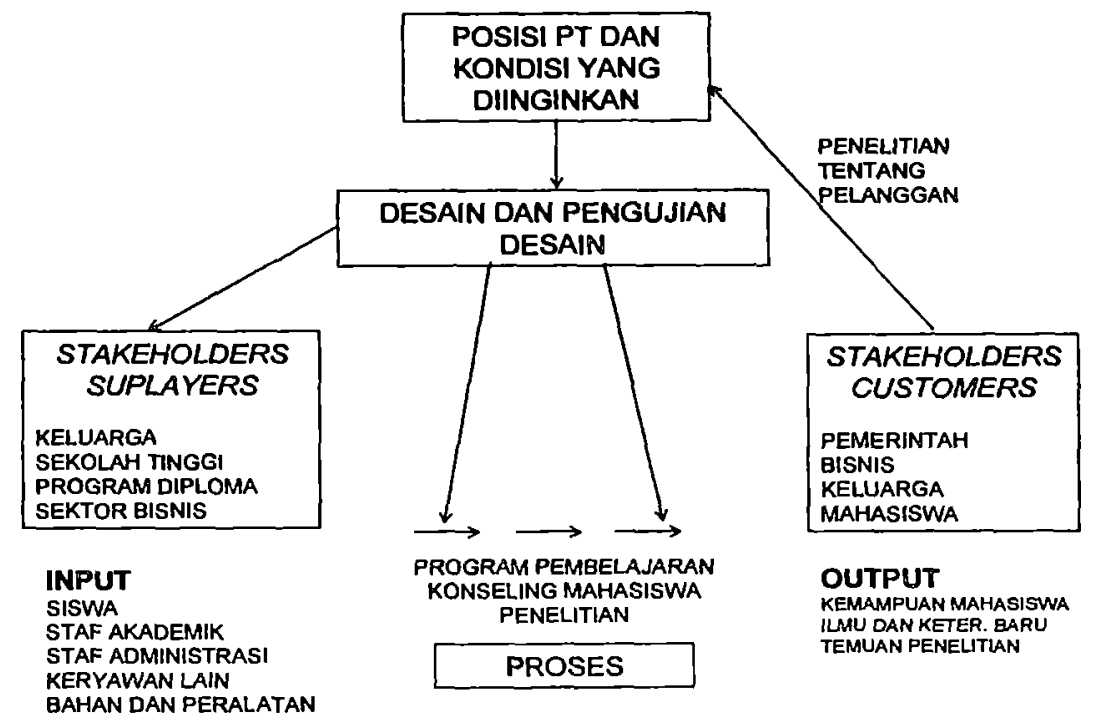

Berkaitan dengan.pelanggan pendidikan, Sallis telah mengklasifikasikan "pelanggan" agar dapat lebih mudah untuk memahami makna atau siapakah para pelanggan pendidikan secara keseluruhan.

Education (value added to Learners): The Service

The Learners

: Primary external costomer or Client

Parents/Governors/Employers

: Secondary external costomer

Labour Market/Goverment/Society

: Tertiary external costomer

Teachers/Support Staff

$\therefore$ Internal Costomer ${ }^{20}$ 
Adanya perbedaan pelanggan ini maka diperlukan suatu perhatian khusus dari lembaga pendidikan pada keinginan pelanggannya. Hal ini penting untuk mengembangkan mekanisme pelayanan pendidikan yang diberikan. Jika perhatian khusus terhadap perbedaan yang ada diabaikan oleh pimpinan lembaga pendidikan, akan berdampak pada kehilangan pelanggan potensia ${ }^{21}$.

Dengan demikian, suatu batasan perlu ditetapkan antara "pelanggan internal" dan "pelanggan eksternal" dari lembaga pendidikan. Fokus utama dalam konsep Total Quality Management adalah pada pelanggan internal yaitu untuk merubah hubungan internal menjadi lebih operasional tanpa adanya konflik internal dan persaingan, sebagai tim yang nyata dengan sasaran utama pada pemuasan pelanggan. Sedangkan fokus utama dari pemasaran PT adalah pada pelanggan eksternal, yaitu calon peserta pendidikan/mahasiswa, orangtua dan lain-lain yang termasuk dalam pelanggan eksternal.

\section{Pemasaran dan Pembentukan Citra PT}

Pemasaran memiliki definisi yang beragam, tetapi pada intinya pemasaran merupakan usaha/ kegiatan yang menyalurkan barang dan jasa dari produsen ke konsumen untuk memenuhi kebutuhan konsumen melalui proses pertukaran ${ }^{22}$. Pemasaran hampir dilakukan oleh setiap lembaga walaupun selama ini kebanyakan orang hanya beranggapan bahwa organisasi bisnis sajalah yang melakukan fungsi pemasaran. Kenyataan ini diungkapkan oleh Morris dalam Kotler bahwa dewasa ini tidak ada organisasi baik itu bisnis atau non-bisnis yang dapat terlepas dari pemasaran (marketing), organisasi tersebut dapat memilih untuk mengerjakannya demi kebaikan organisasi atau meninggalkannya untuk kemundurannya ${ }^{23}$.

Dalam lembaga PT pemasaran didefinisikan sebagai pengolahan yang sistematis dari pertukaran nilai-nilai yang sengaja dilakukan untuk mempromosikan misi-misi PT berdasarkan pemuasan kebutuhan nyata baik itu untuk konsumen ataupun masyarakat sosial pada umumnya ${ }^{24}$. Dalam hal yang hampir senada, definisi dikemukakan oleh Evans yang menyatakan bahwa pemasaran di PT merupakan proses manajemen yang bertujuan untuk melakukan identifikasi dan memberikan kepuasan terhadap pelanggan dan masyarakat secara terus menerus dan berkesinambungan ${ }^{25}$. 
Jelas, bahwa pemasaran merupakan suatu proses yang harus dilakukan oleh PT untuk memberikan kepuasan pada pelanggan dan masyarakat. Penekanan kepada pemberian kepuasan kepada pelanggan dan masyarakat merupakan hal yang harus dilakukan oleh setiap lembaga, jika lembaga tersebut menginginkan untuk mampu bersaing. Pemberian kepuasan secara terus menerus dan berkesinambungan mengindikasikan adanya proses layanan yang harus selalu melakukan inovasi dan pengembangan, karena kepuasan pelanggan merupakan proses yang selalu berubah.

Untuk itulah pimpinan PT harus melakukan/ menjalankan PT yang dipimpinnya dengan menggunakan teknik-teknik manajemen profesional yang telah banyak dilakukan di perusahaan-perusahaan profit/ bisnis. Memang benar, laba "bukan" merupakan tujuan organisasi ini, walaupun demikian PT perlu untuk mendapatkan dana dan dana tersebut utamanya berasal dari mahasiswa karena mahasiswa telah mengeluarkan uang/ dana yang besar untuk PT maka sewajarnyalah jika PT memberikan perhatian utamanya terhadap mahasiswa. Oleh karena itulah tidak berlebihan apa yang digambarkan oleh Batty dalam Kriegbaum tentang besarnya biaya pendidikan. Harga pendidikan tinggi adalah merupakan suatu investasi yang besar ${ }^{26}$. Gambaran ini menunjukkan betapa sulitnya menentukan biaya di PT yang tepat, di satu sisi PT sebagai lembaga sosial harus mampu membuat biaya pendidikan yang ditanggung oleh mahasiswa sekecil mungkin, namun disisi lain PT tidak mampu melakukan pengembangan yang berarti jika tidak memiliki dana yang cukup.

Hal ini membutuhkan kemampuan pemimpin PT (Rektor) sebagai manajer dalam mengelola dan mendapatkan dana secara mandiri khususnya bagi PT, kenyataan ini sesuai dengan PP 60/1999 Pasal 114. Untuk itu pemimpin PT hendaknya memiliki berbagai keterampilan dan cara-cara yang strategis untuk mengembangkan berbagai sumber daya, mengintegrasikan berbagai jadwal, menentukam sasaran komunikasi, mengontrol berbagai persepsi dan membuat presentasi.

Clungston memberikan gambaran tentang keterikatan antara fungsi pemasaran di PT dengan fungsi kepemimpinan seperti yang terlihat dalam gambar 5:

Lingkaran A dan B mewakili keseluruhan PT (A dan B adalah satu lingkaran) lingkaran $\mathrm{C}$ merupakan fungsi kepemimpinan dalam pengembangan organisasi. Hubungan antara lingkaran $C$ dan $D$ merupakan aktivitas perencanaan 
strategis (conceptualizing function) dari pemimpin (president). Hubungan antara lingkaran $\mathrm{C}$ dan $\mathrm{B}$ diwakili aktivitas pemasaran berdasarkan kepemimpinan yang dilaksanakan sehari-hari (nampak) CD dan CB berinteraksi secara serempak. Rektor, sebagai contoh, melakukan baik perencanaan strategis dan operasional maupun pengaktualisasian dalam pemasaran untuk mengembangkan organisasi. Jadi jelaslah bahwa pemasaran di PT harus dilakukan dengan perencanaan yang baik. Hal ini harus dilakukan oleh rektor sebagai pimpinan PT.

Gambar 5: Keterkaitan antara Fungsi Pemasaran dengan Kepemimpinan ${ }^{27}$

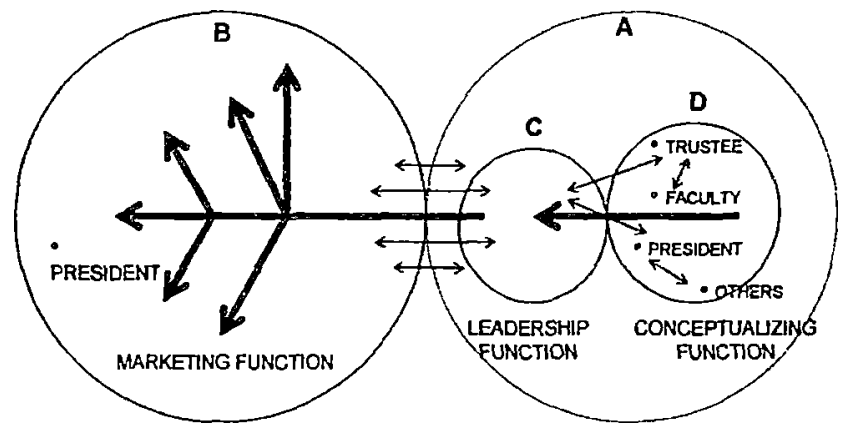

Dengan demikian salah satu fungsi pemasaran di PT pada dasarnya adalah untuk membentuk citra baik terhadap lembaga dan menarik sejumlah calon mahasiswa, sehingga calon mahasiswa lebih tertarik untuk masuk PT tersebut, yang pada akhirnya tentu akan lebih banyak dana yang bisa dikumpulkan dan pengembangan PT dapat dilakukan sebagaimana yang telah direncanakan.

Philip Kotler dalam Topor menyatakan bahwa Image is Power. Citra yang positif merupakan aset yang sangat berharga di pasar (marketplace) ${ }^{28}$. Contoh yang baik pada citra ini dapat dilihat pada persaingan dalam penjualan barangbarang habis pakai (misal; shampo, sabun dan sebagainya). Satu merk shampo ada yang terkenal, walaupun secara kualitas terdapat beberapa merk shampo yang lain yang dengan kualitas sama bahkan lebih baik tetapi karena shampo yang sudah terkenal tadi selalu menjaga kualitas pemasarannya maka reputasi produknyapun (branch equity) tetap baik dan pembeli akan selalu mengingat merk shampo tersebut begitu akan membeli shampo ${ }^{29}$. 
Berbagai jenis produk juga selalu di citrakan dengan hal-hal lain yang baik, bahkan seringkali bertentangan bahkan tidak ada hubungannya sama sekali. Produk sabun dicitrakan dengan kecantikan, kelembutan, keputihan, dan keindahan bahkan seringkali dicitrakan dengan kegesitan, keberuntungan dan kecerdasan. Produk rokok yang jelas-jelas merugikan kesehatan dicitrakan dengan kegagahan, keberanian, kecerdasan, kreatifitas, keharmonisan, keinginan untuk suka menolong dan kesemarakan. Jelas sekali bahwa produk yang dihasilkan tidak ada hubungan sama sekali dengan citra yang akan dibangunnya, namun demikian seiring dengan perkembangan media, pembangunan citra dapat dilakukan lebih intensif dan lebih persuasif, sehingga suatu produk rokok tidak lagi memiliki citra rokok sebagai suatu barang yang merugikan kesehatan, tetapi sudah memiliki citra yang berbeda.

Itulah sebabnya PT harus mampu membangun citra (image building) dan selalu melakukan asesmen terhadap citranya di masyarakat. Pengukuran citra dapat dilakukan terhadap; 1) pengunjung web site, 2) calon mahasiswa potensial, 3) orang tua, 4) konselor, 5) mahasiswa peserta program matrikulasi, 6) mahasiswa, 7) lulusan, 8) alumni, 9) mahasiswa transfer, 10) kawan sebaya, 11) mahasiswa drop out, 12) mahasiswa usia dewasa (adult lerners) ${ }^{30}$.

Selain terhadap populasi-populasi di atas pengukuran citra juga harus dilakukan untuk dapat menghasilkan analisa kompetitif. Sehingga dibutuhkan pengukuran citra pada berbagai hal yang berkaitan dengan kompetitor. Topor memberikan daftar audience yang dapat dilakukan pengukuran untuk mengetahui citra PT dibandingkan dengan kompetitornya, yang meliputi; 1) Editor pendidikan pada surat kabar lokal, 2) Pimpinan PT dari PT kompetitor, 3) Pekerja potensial, 4) Profesional bisnis, 5) Lembaga akreditor, 6) Wartawan, 7) Anggota dewan, 8) Pimpinan daerah, 9) Pimpinan nasional (jika dibutuhkan ), 10) masyarakat sekitar, 11) dosen-dosen dari PT kompetitor, 12) mahasiswa dari PT kompetitor ${ }^{31}$.

\section{E. Pemasaran di Perguruan Tinggi}

Fungsi pemasaran dilembaga pendidikan adalah untuk membentuk citra baik terhadap lembaga dan menarik minat sejumlah calon mahasiswa. Oleh karena itu pemasaran harus berorientasi kepada "pelanggan" yang dalam konteks PT disebut dengan mahasiswa. Disinilah periunya PT untuk mengetahui bagaimanakah calon mahasiswa melihat PT yang akan dipilihnya. Moll menyatakan beberapa 
isu yang menjadi perhatian calon mahasiswa sebelum memilih PT, isu-isu tersebut tentu saja sesuai dengan keadaan waktu itu, isu-isu tersebut antara lain. 1) PT yang lebih prestisius adalah lebih bagus, 2) masalah tempat atau lokasi kampus, 3) Semakin kecil PT maka hubungan antar personal semakin akrab, 4) Beberapa PT unggul disalah satu bagian saja, misalnya di jenis pendidikan liberal art ataupun profesional art saja, 5) PT yang menerima jurusan satu jenis kelamin saja akan gulung tikar, 6) Beberapa PT sekarang ini tidak hanya didominasi oleh orang kaya tetapi juga orang miskin ${ }^{32}$. Walaupun kondisi di Indonesia tidak sama persis dengan yang ada di Amerika, namun beberapa isu masih sangat relevan, misalnya isu nomer 1, 2, 4 dan sekarang isu nomer 6 tentang mahalnya biaya PT sedang banyak dikeluhkan oleh masyarakat.

Seperti telah dinyatakan sebelumnya bahwa pemasaran adalah kegiatan/ pendekatan yang selalu berorientasi pada konsumen yang bertujuan untuk membuat keputusan manajemen. Oleh karena itu pemasaran hendaknya dilakukan dengan perencanaan yang matang dan tujuan yang jelas. Drucker memberikan langkahlangkah untuk memenangkan persaingan dengan menggunakan pemasaran;

1. Tujuan harus didefinisikan secara jelas, yang mencakup hasil, proses dan juga strategi

2. Buatlah rencana pemasaran dan usaha-usaha pemasaran untuk masingmasing kelompok sasaran;

3. Lakukan komunikasi baik kedalam maupun keluar PT serta lakukanlah pelatihan

4. Daftarlah kebutuhan logistik yang dibutuhkan ${ }^{33}$.

Baru setelah keempat hal ini anda laksanakan anda akan dapat menilai hasilnya. Disamping itu PT juga perlu untuk mengutamakan kebutuhan khusus masyarakat yang diperkirakan dapat memuaskannya. PT juga harus mempromosikan berbagai hal kepada kelompok-kelompok masyarakat yang paling potensial. Pendekatan ini bertentangan dengan pola-pola tradisional yang bertitik tolak dari pengidentifikasian kebutuhan PT dan kemudian berusaha untuk mempengaruhi donatur dan calon mahasiswa yang sesuai dengan karakteristik $\mathrm{PT}^{34}$. Pendapat di atas mengidikasikan bahwa $\mathrm{PT}$ harus mampu membuat program-program layanan pendidikan yang berorientasi kepada masyarakat sebagai pangsa pasar pendidikan, bukan masyarakat yang menyesuaikan dengan kebutuhan PT 


\section{a. Perencanaan}

Perencana pemasaran menyeluruh harus merupakan bagian dari rencana institusional yang paling besar. Rencana pemasaran menunjuk pada proses dua arah yang menyeluruh, hal tersebut tidak hanya termasuk dalam aktivitas penerimaan mahasiswa secara tradisional tetapi juga research pasar yang meliputi pekerja dan survey kebutuhan calon mahasiswa yang potensial, analisa citra masyarakat terhadap $\mathrm{PT}$, penelitian tentang alur kebutuhan, komunitas dan profil calon mahasiswa, evaluasi program dan retensi dari survey yang telah dilakukan. Kenyataan ini seperti yang diungkapkan oleh Moll dalam penelitiannya terhadap PT-PT yang ada di Amerika. Terdapat beberapa hal yang dilakukan oleh PT dalam menghadapi ramalan tentang menurunnya jumlah mahasiswa pada waktuwaktu yang akan datang. Kebanyakan PT akan lebih meningkatkan diri serta membuat perencanaan pemasaran terpadu bersama-sama dengan analisa-analisa yang lain, semacam; analisa pasar, dukungan keuangan, student flow, retention dan sebagainya ${ }^{35}$.

Hal pertama yang harus dilakukan daiam membuat rencana pemasaran adalah dengan menentukan visi, misi, tujuan umum, tujuan khusus $\mathrm{PT}^{36}$. Penentuan keempat hal tersebut penting sekali karena bagaimanapun strategi pemasaran yang akan dibuat tentunya harus tidak terlepas dari visi, misi, tujuan umum, dan tujuan khusus yang ingin dicapai oleh PT. langkah berikutnya adalah menganalisis ancaman dan peluang eksternal. Lingkungan eksternal tempat organisasi bergerak sangat komplek dan selalu berubah oleh karena itu PT harus mengetahui peluangpeluang dan tantangannya. Kotler \& Andreasen, menjabarkan lingkungan eksternal menjadi 4 hal meliputi;

1. Lingkungan publik yang terdiri dari kelompok atau organisasi yang tertarik pada kegiatan lembaga

2. Lingkungan kompetitif, terdiri dari lembaga lain yang bersaing untuk mendapatkan perhatian atau loyalitas dari kelompok sasaran

3. Lingkungan makro yang terdiri dari kekuatan fundamental berskala besar yang membentuk peluang dan ancaman terhadap lembaga tersebut

4. Lingkungan pasar, yang terdiri dari kelompok dan organisasi lain yang bekerjasama dengan lembaga tersebut untuk mencapai visi dan misi mereka ${ }^{37}$. 
Supaya PT dapat melaksanakan pemasaran dengan berhasil, PT hendaknya mengetahui kecenderungan "kondisi pasar" terlebih dahulu. PT harus dapat mengembangkan pendidikannya bagi berbagai macam segmen pasar, oleh karena itu kurikulum yang dihasilkan oleh $\mathrm{PT}$ harus benar-benar berorientasi pada keinginan dan kebutuhan "pelanggan". Untuk memperluas segmentasi pasar tersebut PT hendaknya menawarkan berbagai jenis pendidikan (sebagai produk) kepada pasar, strategi ini dicontohkan oleh Kotler \& Murphy pada tabel 2.

Tabel 2: Macam-macam pendidikan (sebagai produk) dalam keterkaitannya dengan pasar $^{38}$

\begin{tabular}{|c|c|c|c|}
\hline \multirow[b]{2}{*}{ Pasar } & \multicolumn{3}{|c|}{ Produk } \\
\hline & Yang ada & Modifikasi & Baru \\
\hline Yang ada & 1. Rembesan pasar & $\begin{array}{l}\text { 4. Modifikasi } \\
\text { produk } \\
\text { - Program pagi } \\
\text { - Program akhir } \\
\text { minggu } \\
\text { - Sistem } \\
\text { penyampaian } \\
\text { baru }\end{array}$ & $\begin{array}{l}\text { 7. Inovasi produksi } \\
\text { - Materi (courses) } \\
\text { baru } \\
\text { - Jurusan baru } \\
\text { - Sekolah baru }\end{array}$ \\
\hline Geografis & $\begin{array}{l}\text { 2. Perluasan } \\
\text { wilayah } \\
\text { - Perluasan } \\
\text { wilayah dalam } \\
\text { kota } \\
\text { - Kota baru } \\
\text { - Luar negeri } \\
\end{array}$ & $\begin{array}{l}\text { 5. Modifikasi untuk } \\
\text { memperluas } \\
\text { pasar } \\
\text { - Program untuk } \\
\text { militer } \\
\text { - Program untuk } \\
\text { perusahaan } \\
\end{array}$ & 8. Inovasi geografis \\
\hline Baru & $\begin{array}{l}\text { 3. Pasar baru } \\
\text { A. Individu } \\
\text { - Pendidikan } \\
\text { untuk orang } \\
\text { dewasa } \\
\text { - Pendidikan } \\
\text { untuk ibu-ibu } \\
\text { rumah tangga } \\
\text { B. Lembaga } \\
\text { - lembaga bisnis } \\
\text { - agen sosial }\end{array}$ & $\begin{array}{l}\text { 6. Modifikasi untuk } \\
\text { pasar baru } \\
\text { A. Individual } \\
\text { - Pendidikan } \\
\text { untuk orang } \\
\text { dewasa } \\
\text { B. Lembaga } \\
\text { - Bisnis } \\
\text { - pemerintahan }\end{array}$ & $\begin{array}{l}\text { 9. Total inovasi } \\
\text { - Materi baru } \\
\text { - Jurusan baru } \\
\text { - Sekolah baru }\end{array}$ \\
\hline
\end{tabular}


- Jurusan baru

- Sekolah baru

Sel nomer 1 dinamakan market penetration (rembesan pasar). Dibawah strategi ini institusi mencari sejumlah besar pendaftar yang sesuai dengan programprogram yang ada. PT di kota besar dengan pasar yang kecil dapat memanfaatkan strategi ini. Promosi besar-besaran akan sangat penting untuk membuat strategi iniberjalan.

Sel nomer 2 dinamakan Geographic Expansion (perluasan wilayah). Strategi ini diterapkan dengan membuka beberapa kampus cabang di kota atau daerah lain. Di Indonesia pembukaan PT cabang ini masih menjadi masalah dikarenakan kekuatiran akan adanya perbedaan mutu yang tajam antara PT induk dan PT cabang, namun demikian secara realitas banyak PT yang memiliki kelaskelas jauh di berbagai daerah Di Amerika PT cabang juga ada, misal; Univresitas Dallas membuka program MBA di Houston, atau Antioch College membuka kampus diluar negeri.

Kemungkinan ketiga untuk meningkatkan ketertarikan pada produk-produk yang ada adalah disebut dengan new markets (pasar baru). Universitas hendaknya meningkatkan penerimaan mahasiswa baru yang berasal dari kelompok-kelompok non-tradisional, seperti orang dewasa, ibu-ibu rumah tangga, para karyawan, lembaga-lembaga bisnis, agen-agen sosial atau kelompok-kelompok non-tradisional lain yang potensial.

Sel ke 4, menunjukkan bahwa program dapat dimodifikasi untuk dapat menarik pasar yang telah ada. Program-program pagi untuk sekolah didalam kota besar, program akhir minggu bagi orang-orang yang tidak dapat mengikuti kelas reguler, atau menggunakan sistem belajar yang berbeda dengan sistem belajar konvensional

Sel ke 5 dinamakan modification for dispersed markets (modifikasi untuk memperluas pasar). PT dapat membuat program-program yang digunakan untuk pangsa pasar khusu, misalnya program pembelajaran untuk para instruktur militer, atau para technical training di perusahaan. Bebera PT di Indonesia memiliki program ini. 
Sel ke 6 dinamakan modification for new markets (modifikasi pasar baru). Program ini merupakan program yang lebih realistis untuk meningkatkan/ menumbuhkan universitas. Program ini merupakan terobosan yang paling berhasil untuk mengatasi pasar mahasiswa yang sedang turun. Misalnya membuat program-program untuk lembaga bisnis, lembaga-lembaga pemrintah, lembagalembaga keagamaan ataupun lembaga-lembaga swadaya masyarakat yang membutuhkan pendidikan bagi karyawan-karayawannya.

Sel ke 7 dinamakan product inovation (inovasi produk), PT membuka program studi-program studi/ jurusan-jurusan baru untuk memenuhi kebutuhan pasar yang telah ada misalnya, program D-II Jamu dan Obat Tradisional di Universitas Gadjah Mada merupakan jenis inovasi produk dari PT yang disediakan untuk pasar industri jamu dan obat tradisional yang banyak di daerah Jawa Tengah dan Yogyakarta.

Sel ke 8 dinamakan geographic innovation dapat dicapai dengan menggunakan teknologi, misalnya pengajaran dengan menggunakan telepon, komputer jarak jauh, dan televisi dan teknologi media yang lain.

Sel ke 9 disebut total innovation (inovasi menyeluruh) dengan produk dan pasar baru. Hal ini bisa disebut juga dengan "universitas tanpa dinding". Peserta pendidikan tidak perlu datang ke kelas atau sekolahan yang selama ini dilakukan, mahasiswa tinggal melihat televisi yang ada dirumah atau menggunakan jaringan komputer yang ada dirumahnya.

Selain itu dalam melihat segmen pasar ini PT juga harus menentukan calon mahasiswa yang akan dipilihnya. Moll memberikan 5 kategori berdasarkan PTPT yang ada di Amerika:

1) berdasarkan intelektual (intellects), ini berarti bahwa PT akan menerima calon mahasiswa berdasarkan kemampuan intelektualnya. Di Indonesia keadaan ini paling banyak dilakukan sehingga beberapa PT akan melaksanakan tes terlebih dahulu terhadap calon mahasiswa yang berminat masuk ke PT tersebut;

2) berdasarkan bakat khusus (special talent), ini berarti bahwa PT akan menerima langsung calon-calon mahasiswa yang memiliki bakat-bakat khusus semacam kesenian, olah raga dan sebagainya. Kategori ini juga banyak digunakan oleh PT-PT yang ada di Indonesia semacam pemberlakuan bebas tes bagi atlit-atlit sepak bola, atau jenis olah raga lain yang lain oleh PT; 
3) berdasarkan keluarga (the family), PT yang menerima mahasiswa dari keterkaitan dengan keluarga misalnya pemberlakuan khusus bagi mahasiswa yang berasal dari alumni PT yang bersangkutan ataupun yang lain. Di Indonesia walaupun tidak banyak ada beberapa PT yang memberlakukan sistem ini semacam, pemberlakuan khusus bagi calon mahasiswa yang berasal dari keluarga ABRI di UPN (Universitas Pembangunan Nasional);

4) berdasarkan keinginan sosial (Social Conscience), ini berarti bahwa PT akan menerima calon mahasiswa berdasarkan keinginan-keinginan sosial yang ada di masyarakat, misalnya keinginan masyarakat kulit hitam yang ada di Amerika atau keinginan masyarakat-masyarakat minoritas tertentu.

5) berdasarkan semua anak Amerika (the all Americans Kid), kebanyakan semua calon mahasiswa masuk dalam kategori ini, yang mana PT akan menerima semua calon mahasiswa yang berasal dari Amerika. Kondisi sama dengan di Indonesia. PT-PT di Indonesia akan menerima calon mahasiswa darimanapun asal mahasiswa tersebut ${ }^{39}$.

Terakhir, PT harus dapat menganalisa perbandingan antara besarnya peluang dan ancaman (resiko) dalam lingkungan eksternal yang dihadapi oleh PT tersebut dengan memperhatikan kekuatan dan kelemahan yang dimiliki oleh PT. untuk mengikuti langkah-langkah perencanaan diatas PT hendaknya mengetahui "segmen pasar pasarannya", memiliki posisi kompetitif, dan mengembangkan bauran pemasaran yang efektif untuk melayani calon mahasiswa terpilih ${ }^{40}$.

Proses analisis tersebut akan menjadikan bahan informasi yang sangat berhaga bagi manajemen PT dalam memenangkan persaingan. Evans memberikan alur sistem informasi di bidang pemasaran PT seperti pada gambar 6

Gambar 6: Model Sistem Informasi Pemasaran di PT ${ }^{41}$

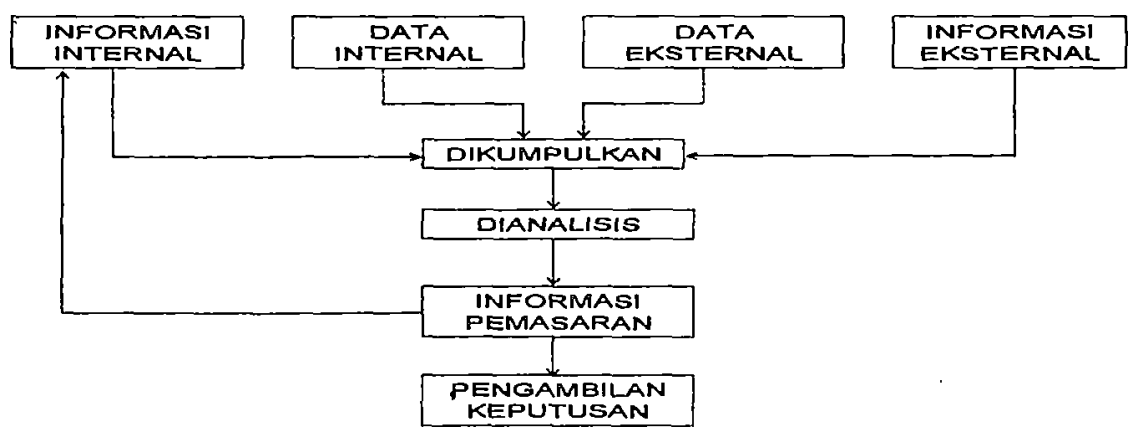

Ulul Albab, Vol. o No. 1, 2UU5 


\section{b. Pelaksanaan}

Dalam pelaksanaan pemasaran di PT hendaknya memperhatikan variabelvariabel yang dapat menarik minat mahasiswa. Variabel-variabel tersebut ada yang dapat dikontrol oleh PTS ada pula yang tidak dikontrol. Adapun variabel yang tidak dapat dikontrol tersebut antara lain; budaya, kondisi ekonomi, dan kecenderungan sosial. Sedangkan variabel-variabel yang dapat dikontrol meliputi ;1) Kurikulum atau pelayanan lembaga pendidikan yang cocok dengan lembaga users; 2) Lokasi pelayanan, disini termasuk juga pelayanan diluar kampus dengan menggunakan media semacam perkuliahan jarak jauh dengan TV; 3) Komunikasi dengan mahasiswa, alumni, donatur, atau komunitas lain yang terkait dengan praktek promosi di dunia bisnis; 4) Besarnya uang kuliah yang memungkinkan sekolah untuk melayani mahasiswa dengan baik dan efisien ${ }^{42}$.

Sedangkan Alma dengan melihat kondisi pendidikan yang ada di Indonesia menyatakan bahwa elemen bauran pemasaran di lembaga pendidikan meliputi 4P ditambah satu elemen bauran P. elemen-elemen tersebut adalah Product, Price, Place, Promotion, Personal Trait. Informasi tentang adanya P1, P2, P3, P4 dan P5 akan diperoleh oleh calon mahasiswa dari berbagai sumber seperti dari mass media, orang tua, famili, alumni, guru sekolah, mahasiswa yang masih aktif kuliah dan sebagainya. Disamping itu ada empat faktor lain yang turut mempengaruhi pilihan mahasiswa yaitu lingkungan sosio kultural dari calon mahasiswa berasal, apakah dia cocok bergaul dilingkungan perguruan tinggi yang akan ia masuki. Lingkungan politik dan hukum, lingkungan ekonmomi dan teknologi, lingkungan kompetitif, dan lingkungan sumber daya semuanya menjadi bahan pertimbangan calon untuk memasuki sebuah perguruan tinggi ${ }^{43}$.

Dari kedua pendapat tersebut secara tersirat memiliki kesamaan. Kurikulum misalnya merupakan unsur yang sangat potensial dalam menentukan produk PT. Kertajaya menyatakan bahwa suatu industri jika selalu ingin laku dipasaran harus selalu mengembangkan produk baru (new product develepment) yang sesuai dengan kebutuhan (need), keinginan (want) dan jika perlu sesuai dengan harapan (expectation) dari konsumen ${ }^{44}$. Kenyataan ini juga berlaku bagi PT dalam kondisi sekarang ini, karena banyaknya PT maka persaingan merupakan sesuatu yang tidak dapat dihindari. Jika PT-PT tersebut tidak membuka jurusan-jurusan atau program studi-program studi yang dibutuhkan oleh masyarakat, tentu PT tersebut 
lambat laun akan ditinggalkan oleh masyarakat. Kondisi ini tentunya juga menuntut perubahan/ pembuatan kurikulum baru menjadi lebih menarik dan sesuai dengan kebutuhan, keinginan dan harapan yang ada dimasyarakat.

Berkaitan dengan produk PT adalah biaya, strategi biaya yang tepat merupakan sesuatu yang sangat menentukan bagi PT dalam menghadapi persaingan. Secara umum calom mahasiswa akan selalu memilih PT yang memiliki kualitas yang baik dengan biaya yang murah. Kenyataan ini sesuai dengan yang dikemukakan oleh Kertajaya bahwa produk atau value = total quality/total cost artinya jika ingin memenangkan persaingan maka PT harus meningkatkan kualitas dan menurunkan biaya, secara matematik jika pembilang (total quality) dinaikkan dan penyebut (total cost) diturunkan maka akan menghasilkan nilai yang besar pada hasil (produk atau value ${ }^{45}$. Dalam PT tentunya total quality bukan hanya kualitas lulusan saja tetapi juga meliputi layanan-layanan lain yang sesuai dengan kebutuhan, keinginan dan harapan calon mahasiswa.

Tempat/ lokasi juga merupakan sesuatu yang penting, demikian halnya promosi dan reputasi personal merupakan sesuatu yang penting untuk menjaga citra calon mahasiswa terhadap reputasi PT. Citra terhadap reputasi PT ini perlu untuk selalu dijaga agar PT tersebut selalu dikenal baik oleh masyarakat.

Promosi dan pendaftaran mahasiswa baru (recruitment) juga merupakan sesuatu yang harus diperhatikan, salah satu kegiatan promosi adalah publikasi. Publikasi pada dasarnya adalah bertujuan untuk memperkenalkan PT kepada masyarakat, untuk itu publikasi hendaknya meliputi ; 1) Aturan yang jelas dan syarat-syarat penerimaan mahasiswa baru yang tepat sebagai persiapan bagi siswa-siswa sekolah lanjutan yang hendak masuk ke PT, tes penerimaan, dan syarat-syarat untuk mahasiswa transfer, 2) Kalender penerimaan yang disusun secara tepat; 3) Informasi yang tepat beserta syarat-syarat yang berkaitan dengan keuangan; 4) Menggambarkan dengan detail beberapa program, misalnya program belajar luar negeri, ujian cicilan atau bahkan penempatan setelah lulus; 5) Menggambarkan aturan-aturan kampus dan masyarakatnya secara nyata ${ }^{46}$.

Berbagai aturan-aturan dalam publikasi diatas sebagian besar sudah dilakukan oleh PT-PT yang ada di Indonesia bahkan biasa disertai foto-foto dari berbagai kegiatan yang dilakukan oleh PT tersebut. Walaupun demikian dibandingkan dengan sistem penerimaan di PT yang ada di Amerika masih terdapat beberapa perbedaan. Di Amerika bagian penerimaan mahasiswa merupakan 
bagian tersendiri yang biasa disebut dengan admission office. Terdapat dua bagian dalam departemen penerimaan yaitu admissions counselors dan admissions officers. Aturan-aturan dan syarat-syarat penerimaan mahasiswa baru, penelitian tentang segmentasi pasar, promosi dan publikasi merupakan pekerjaan yang banyak ditangani oleh bagian in ${ }^{47}$. Di Indonesia keadaan seperti di atas belum terlihat ini dikarenakan PT-PT di Indonesia belum menganggap penting bagian ini, tetapi lambat laun dengan makin menurunnya jumlah calon mahasiswa untuk masuk PT dan berkembangnya PT lintas negara, maka bagian ini akan merupakan ujung tombak bagi kelangsungan hidup PT tersebut.

Oleh karena itu variabel-variabel yang dapat dikendalikan oleh PT tersebut harus dipentingkan dan diarahkan untuk kebutuhan dan kepuasan "pelanggan". Kepuasan pelanggan tersebut tentu tidak hanya tergantung pada faktor-faktor yang berhubungan dengan bidang-bidang akademik saja, tetapi juga berhubungan dengan faktor-faktor lain, semisal ketersedian asrama, kehidupan sosial kampus, dukungan psikologi, tim olahraga \& kesenian, dan sebagainya. Kesemua itu harus diperhatikan oleh PT, jika PT tersebut hendak memenangkan persaingan diantara PT-PT yang lain dalam menarik minat "pelanggan". Dengan melaksanakan kegiatan pemasaran akan dapat membantu PT menghadapi masa depan yang lebih baik.

\section{c. Pengendalian}

Untuk mencapai kontrol yang baik PT membutuhkan informasi-informasi yang cukup akurat dan memadai. Kotler \& Andreasen memberikan empat sistem untuk informasi pemasaran organisasi. Keempat sistem tersebut adalah; 1) internal record system, sistem ini meliputi keseluruhan informasi yang berkaitan dengan jumlah mahasiswa pendaftar, biaya pemasaran, calon mahasiswa potensial, segmen pasar dan sebagainya. 2) Marketing intellgence system, meliputi serangkaian sumber dan prosedur yang menyediakan informasi tentang perkembangan yang terjadi di masyarakat yang berkaitan dengan kebutuhan masyarakat terhadap pendidikan tinggi. PT bisa memperbaiki kualitas intellijen pemasaran dengan memperbaiki kualitas "intelijen pemasaran" dengan memotivasi pimpinan PT atau bagian pengembangan PT untuk menemukan variabel lingkungan 
pemasaran yang sesuai dengan PT yang dipimpinnya. 3) marketing research sysytem, terdiri atas desain sistematis pengumpulan, analisis, dan pelaporan data, penemuan masalah spesifik. 4) Analitycal marketing system, terdiri atas dua perangkat pemasaran dan permasalahan pemasaran. Perangkat pertama disebut dengan statistical bank, yang mengkoleksi prosedur statistik untuk melakukan analisa keterkaitan antar data. Perangkat kedua, disebut model bank, yang terdiri atas koleksi model-model matematis yang membantu pimpinan PT membuat keputusan pemasaran yang baik ${ }^{48}$. Keseluruhan sistem informasi tersebut dapat digunakan satu persatu maupun bersama-sama untuk mencari mendapatkan informasi yang akurat yang dibutuhkan oleh PT sebelum melakukan evaluasi dan kontrol pemasaran.

Informasi yang telah didapat tersebut digunakan sebagai acuan dalam pelaksanaan kontrol dan evaluasi. Terdapat tiga jenis kontrol pemasaran yang dapat digunakan oleh organisasi nir-laba. Oleh karena PT merupakan salah satu jenis organisasi nir-laba maka kontrol dan evaluasi tersebut dapat disesuaikan dengan kondisi PT. ketiga jenis tersebut adalah; 1) Rencana kontrol tahunan, yang meliputi monitoring pada kinerja pamasaran yang berlangsung untuk meyakinkan bahwa volume penjualan tahunan dan keuntungan yang ditergetkan tercapai. Alat utamanya adalah analisis penjualan, analisa pangsa pasar, analisis anggaran pemasaran dan penulusuran sikap pasar. 2) Kontrol profitabilitas, terdiri dari determinasi profibilitas yang aktual dari pemasaran yang telah dilakukan, misalnya kesesuaian program studi yang telah ada dengan kebutuhan yang ada dimasyarakat, segmen pasar, saluran promosi dan sebagainya. Dengan melaksanakan kontrol ini akan dapat diidentifikasi titik-titik kelemahan dalam pelaksanaan pemasaran. 3) Audit pemasaran, yang bertujuan untuk mengalisis tujuan pemasaran, strategi, dan sistem yang diadaptasi secara optimum dan lingkungan tujuan pemasaran yang telah diramalkan ${ }^{49}$.

Adanya pelaksanaan sistem kontrol ini merupakan tindakan koreksi yang dapat digunakan baik untuk jangka pendek maupun jangka panjang. Meskipun begitu kontrol dan eveluasi secara rutin harus dilaksanakan agar supaya kesalahan yang telah dilakukan oleh PT dapat cepat diperbaiki dan antisipasi selanjutnya dapat dilakukan dengan cepat untuk perkembangan PT. 


\section{Peran elemen-elemen Bauran Pemasaran Dalam Lembaga Pendidikan}

Seperti dijelaskan diatas bahwa elemen-elemen bauran pemasaran meliputi unsur-unsur yang biasa disebut dengan 5P. elemen pertama adalah Product, merupakan hal yang paling mendasar yang akan menjadikan preferensi pilihan bagi calon mahasiswa. Bauran produk dalam strategi ini dapat berupa diferensiasi produk yang akan memberikan dampak terhadap kesempatan lapangan kerja dan menimbulkan citra terhadap nama universitas, dan terhadap mutu produk itu sendiri. Misalnya jurusan apa yang tersedia pada satu universitas, ada jurusan favorit dan ada yang tidak, layanan akademik, layanan administratif. Demikian pula performance dari lulusan jurusan tertentu pada universitas tersebut, turut mempengaruhi pilihan calon ${ }^{50}$.

Kotler \& Andreasen memberikan contoh seperti pada gambar 7.

Gambar 7 Posisi Kompetitif Suatu PT ${ }^{51}$

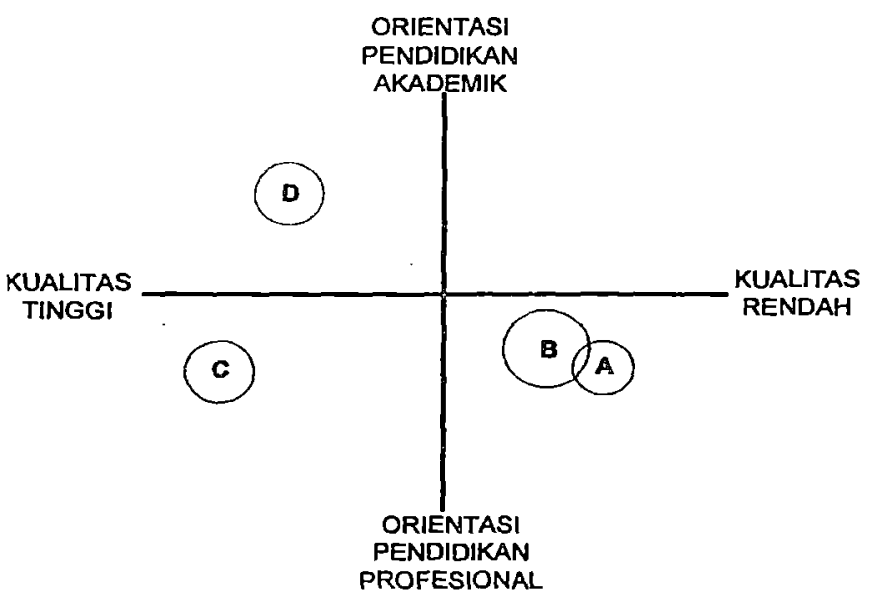

Gambar tersebut menunjukkan posisi kompetitif dari suatu PT (D) terhadap perguruan tinggi lainnya (A, B, C). PT A dan B merupakan PT yang berorientasi pada pendidikan profesional dan memiliki kualitas yang rendah, PT B lebih besar dan sedikit berkualitas dibandingkan dengan PT A. Mereka terjebak dalam persaingan memperebutkan calon mahasiswa yang sama, karena karakteristik 
produk mereka yang hampir bersamaan. PT C dipandang sebagai sekolah yang berorientasi pendidikan profesional dengan kualitas yang tinggi dan menarik banyak calon mahasiswa yang mencari program itu. PT D, karena dipandang mempunyai kualitas yang tinggi dan berorientasi pada akademik, tidak mempunyai saingan untuk segmen tersebut. Hanya terdapat pertanyaan apakah Cukup terdapat banyak calon mahasiswa yang mencari program tersebut? Jika tidak, maka PT D posisi kompetitifnya tidak dapat bertahan, dan manajemen PT D harus memikirkan tentang memposisikan kembali programnya terhadap bagian pasar yang mempunyai segmen pasar lebih besar. Contoh ini jelas menunjukkan betapa pentingnya produk dari suatu PT yang dalam contoh tersebut berupa jurusan yang akan diminati oleh mahasiswa.

Price, merupakan elemen yang berjalan sejajar dengan mutu produk. Tujuan biaya di PT adalah untuk mencapai keseimbangan antara biaya yang digunakan untuk "produksi" dalam institusi tersebut dengan konsumen yang membeli produk tersebut. Kenyataan ini seperti yang dikemukakan oleh Batty (1978) bahwa "The objective of pricing is to achive a balance between the cost of institution's "product" and those consumers who are willing to purchase the product at the price offered". Apabila mutu produk baik, maka calon mahasiswa berani membayar lebih tinggi. Mutu produk akan sangat terkait dengan biaya, karena ini akan sangat mempengaruhi posisi kompetitif terhadap perguruan tinggi saingan. Kenyataan tersebut digambarkan oleh Kriegbaum dalam bentuk sebuah matrix seperti pada gambar 8.

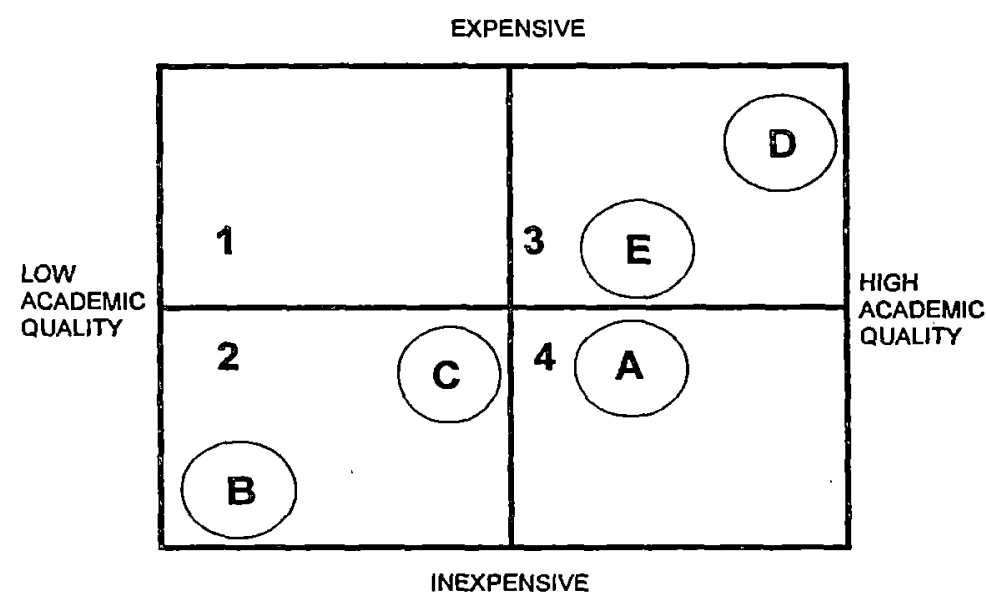

Ulul Albab, Vol. 6 No. 1, 2005 
A, B, C, D dan E merupakan PT yang sedang berkompetisi untuk memperebutkan pasar mahasiswa baru, tiga PT A, C, E berada ditengah matrix, yang berarti bahwa ketiga PT tersebut memiliki kualitas dan biaya kuliah yang tengah-tengah (moderate), dua PT yang lain tidak setengah-setengah (extremes) yang satu dengan biaya mahal tetapi sangat berkualitas sedangkan yang satunya lagi dengan biaya murah dan tidak memiliki kualitas yang baik. Tidak satupun dari kelima PT tersebut yang mematok biaya mahal dengan kualitas yang rendah.

Contoh lain, bila SPP/DPP dinaikkan apakah minat masuk PT berkurang? Tidak, sepanjang SPP tersebut masih dirasa dalam batas keterjangkauan mahasiswa. Akan tetapi ada perguruan tinggi yang menetapkan SPP tinggi sekali, peminatnya tetap banyak. Ini disebabkan karena situasi kelangkahan penyediaan jasa pendidikan yang bermutu (sekurang-kurangnya menurut persepsi "konsumen"), melihat siapa dibelakang pengelola jasa pendidikan tersebut. Malahan pernah ada lembaga pendidikan baru muncul dengan harga tinggi, dan peminatnya besar. Hal ini merupakan taktik "skiming price" yang terkenal dalam marketing, diimbangi dengan bayangan mutu yang meyakinkan ${ }^{53}$.

Para pemimpin PT sependapat bahwa faktor place seperti lokasi, letak PTyang mudah dicapai kendaraan umum, kondisi kampus, cukup berperan sebagai bahan pertimbangan calon mahasiswa untuk memasuki PT. Demikian pula para mahasiswa menyatakan bahwa lokasi suatu PT turut menentukan pilihan mereka, mereka menyenangi lokasi di kota dan yang mudah dicapai kendaraan umum .

Promotion merupakan usaha untuk meningkatkan masuknya calon mahasiswa baru ke PT yang bersangkutan. Alma mengatakan ada beberapa teknik promosi yang dilakukan oleh PT diantaranya yaitu: 1) publikasi di surat kabar, 2) iklan di radio, 3) memasang spanduk, 4) brosur, 5) buletin, 6) televisi, 7) publikasi di radio, 8) publikasi di surat kabar, 9) mengundang umum, 10) mengundang pelajar, 11) logo, 12) mengundang pejabat, 13) kunjungan ke SLA ${ }^{54}$.

Personal Traits, menyangkut unsur pimpinan PT, tercermin pada siapakah yang memimpin? Dengan demikian strategi memilih siapa saja pimpinan yang akan diangkat, tidak diragukan lagi peranannya dalam mengangkat citra $\mathrm{PT}^{\mathrm{ss}}$. Figur seorang pimpinan universitas dapat membawa perkembangan pesat bagi universitas tersebut, dan dapat pula seorang pimpinan menjatuhkan nama baik lembaga. 


\section{G. Memutuskan}

Pada bahasan ini akan disajikan dari sisi lain. Kalau pada bahasan-bahasan sebelumnya telah diketengahkan berbagai bahasan ditinjau dari PT sebagai pelaku pemasaran, maka pada bahasan ini akan dilihat dari segi calon mahasiswa sebagai pihak yang terkena/ sasaran dari pemasaran yang dilakukan oleh PT.

Seperti telah diketahui pada definisi pemasaran pada bahasan sebelumnya, bahwa dalam pemasaran selalu ada unsur pertukaran (exchange). Karena banyaknya pilihan yang diketahui oleh calon mahasiswa dan adanya unsur pertukaran tersebut, maka calon mahasiswa tentu akan menimang-nimang berbagai pilihan yang telah diketahui tersebut, serta untung ruginya dari pertukaran yang akan dilakukannya tersebut. Tentu dalam memilih sesuatu konsumen/calon mahasiswa akan memilih yang banyak menguntungkannya atau paling tidak dirasa seimbang antara pengorbanan yang dilakukan oleh calon mahasiswa dengan hasil yang didapat nantinya. Kotler \& Andreasen menyatakan bahwa untuk terjadi pertukaran diperlukan 4 syarat, 1) paling sedikit harus ada dua pihak; 2) masingmasing pihak dengan menawarkan sesuatu yang oleh pihak lain dianggap sebagai keuntungannya; 3) masing-masing mampu melakukan komunikasi dan pengiriman; 4) masing-masing bebas untuk menerima maupun menolak tawaran ${ }^{56}$. Untuk itulah sebabnya seorang manajer pemasaran hendaknya mengetahui selera konsumen/ segmen konsumen, karena bagaimanapun juga konsumenlah yang akan memutuskan apakah akan melakukan pertukaran atau tidak.

Untuk memilih suatu PT pada dasarnya calon mahasiswa selalu dihadapkan oleh adanya pilihan-pilihan tentang berbagai PT yang ada. Dari berbagai pilihan tersebut tentu calon mahasiswa akan memilih salah satu dari berbagai pilihan yang tersedia. Karena itu calon mahasiswa harus mengambil keputusan yang paling menguntungkannya. Memutuskan merupakan fungsi berpikir, yang diawali dengan kegiatan memilih. Dalam mengambil keputusan hendaknya didasarkan pada berpikir realistik. Ruch dalam Rakhmat menyebutkan tiga macam berpikir realistik yang deduktif, induktif dan evaluatif ${ }^{57}$.

Deduktif ialah mengambil kesimpulan dari dua pernyataan, yang pertama merupakan pernyataan umum. Dalam logika ini desebut dengan silogisme. Berpikir induktif, sebaliknya dimulai dari hal-hal khusus dan kemudian mengambil kesimpulan umum. Sedangkan berpikir evaluatif adalah berpikir kritis, menilai 
baik buruknya, tepat atau tidaknya suatu gagasan, yang mana gagasan tersebut dinilai berdasarkan kriteria tertentu. Walaupun demikian, keputusan yang kita ambil beraneka ragam, tapi ada tanda-tanda umumnya; 1) keputusan merupakan hasil berpikir, hasil usaha intelektual, 2) keputusan selalu melibatkan pilihan dari berbagai alternatif, 3) keputusan selalu melibatkan tindakan nyata, walaupun pelaksanaannya boleh ditangguhkan atau dilupakan ${ }^{58}$.

\section{a. Faktor-faktor yang mempengaruhi pilihan}

Masih belum banyak lagi yang dapat diungkapkan tentang proses penetapan keputusan-keputusan (penentuan pilihan). Tetapi sudah disepakati, bahwa faktorfaktor personal dan diluar personal amat menentukan apa yang diputuskan itu. faktor personal meliputi kognisi, motif dan sikap ${ }^{59}$. Kognisi artinya kualitas dan kuantitas pengetahuan yang dimiliki. Bila anda tahu bakat anda dibidang A maka anda akan memilih perguruan tinggi yang memiliki jurusan A. Motif juga mempengaruhi pengambilan keputusan. Bila anda ingin memperoleh posisi yang penting di kantor $X$, anda memutuskan untuk bekerja sama dengan $Q$. Sikap, juga faktor penentu lainnya. Bila sikap anda negatif terhadap sesuatu hal, maka anda tentu tidak banyak memperdulikan hal tersebut. Pada kenyataannya, kognisi, motif dan sikap ini berlangsung sekaligus.

Faktor diluar personal yang menentukan penentuan pilihan adalah kesan, impressi, perasaan atau konsepsi yang ada pada orang tersebut mengenai perusahaan, obyek, orang atau lembaga. Hal-hal tersebut diatas disebut dengan citra (image), seperti yang dikemukana oleh Levy dalam Alma. Citra merupakan intrepetasi, seperangkat pengetahuan, dan reaksi-reaksi, hal tersebut merupakan simbol karena hal tersebut bukan merupakan obyek itu sendiri, tetapi merujuk kepada obyek tersebut. Selanjutnya kenyataan fisik produk, brand, dan organisasi, citra termasuk makna, kepercayaan, sikap dan perasanaan-perasaan terhadap sesuatu $^{60}$. Jadi, citra ini dibentuk berdasar pengalaman yang dialami seseorang terhadap sesuatu, sehingga akhirnya membangun suatu sikap mental, sikap mental ini nanti dipakai sebagai pertimbangan untuk mengambil keputusan, karena citra dianggap mewakili totalitas pengetahuan seseorang terhadap sesuatu ${ }^{61}$.

Dalam proses penentuan pilihan bisa terasa sulit bisa juga terasa mudah, kenyataan ini tergantung atas keterlibatan yang dilakukan sebelum melakukan 
pilihan. Keterlibatan ini oleh Kotler \& Andreasen dibagi menjadi dua yaitu keterlibatan tingkat tinggi dan keterlibatan tingkat rendah. Keterlibatan ini dapat mempengaruhi jumlah pertimbangan yang dilakukan oleh pembuat keputusan. Keterlibatan tinggi terjadi jika keputusan baru dibuat untuk pertama kalinya, resiko yang tinggi, tekanan dari kelompok luar yang kuat ${ }^{62}$. Jadi keterlibatan yang tinggi ini dapat berangsur-angsur melemah (rendah) jika keputusan tersebut sudah sering dibuat.

Dalam pembuatan keputusan calon mahasiswa akan membentuk rangkaian pilihan terlebih dahulu, rangkaian pilihan ini bergerak dari sesuatu yang luas kemudian menyempit, sehingga pilihan semakin jelas sebelum akhirnya diputuskan. Rangkaian ini seperti terlihat pada gambar 9.

Gambar 9 : Proses pengambilan keputusan calon mahasiswa dalam memilih $\mathrm{PT}^{63}$.

\begin{tabular}{|c|c|c|c|c|}
\hline Rangkaian & Rangkaian & Rang.per- & Rangkaian & Keputusan \\
\hline Cornell & Cornell & Cornell & Cornell & Cornell \\
\hline Duke & Duke & Duke & Duke & \\
\hline North- & North- & North- & North- & \\
\hline western & western & western & western & \\
\hline Tulane & Tulane & Tulane & Tulane & \\
\hline Dartmouth & Dartmouth & Dartmouth & & \\
\hline Yale & Yale & & & \\
\hline Standart & Standart & & & \\
\hline Harvard & Harvard & & & \\
\hline $\begin{array}{l}\text { DePauw } \\
\text { Lawrence }\end{array}$ & $\begin{array}{l}\text { Rangakain } \\
\text { tak sadar }\end{array}$ & $\begin{array}{l}\text { Rangk. Tak } \\
\text { mungkin }\end{array}$ & $\begin{array}{l}\text { Rangk. Tak } \\
\text { dipilih }\end{array}$ & \\
\hline - & DePauw & Yale & Dartmouth & \\
\hline - & Lawrence & Standart & & \\
\hline • & $\bullet$ & Harvard & & \\
\hline
\end{tabular}

Ulul Albab, Vol. 6 No. 1, 2005 
Rangkaian pilihan ini meliputi rangkaian total yang memperlihatkan semua pilihan tentang PT yang ada, kemudian rangkaian ini dipersempit menjadi rangkaian yang disadari oleh calon mahasiswa, dari sini kemudian nama-nama PT-PT yang pernah didengar oleh calon mahasiswa, dari sini kemudian dipersempit lagi menjadi rangkaian pertimbangan yang berisikan PT-PT yang masuk dalam pertimbangan/ memungkinkan calon mahasiswa saja. Setelah mencari informasi tambahan kemudian calon mahasiswa menggolongkan beberapa PT kedalam rangkaian pilihan, yang pada akhirnya akan dipilih satu diantaranya menjadi suatu keputusan. Untuk itulah PT sebagai suatu organisasi hendaknya mengetahui apakah organisasinya sudah ada dalam rangkaian kesadaran ataupun rangkaian pilihan yang ada dalam suatu segmen

pasar, selain itu PT juga harus mengetahui siapakah pesaingnya, pesaing PT bukan hanya PT lain yang sejenis tetapi juga organisasi-organisasi lain semacam lembaga kursus, ataupun lembaga pendidikan keterampilan lain diluar PT. Jika PT tersebut tidak termasuk dalam rangkaian pilihan maka calon mahasiswa tentunya tidak akan masuk ke PT tersebut. Lebih dari itu jika PT ingin memenangkan persaingan diantara PT-PT yang lain maka PT tersebut harus mengetahui pesaing terkuatnya serta mengamati kelemahan dan kekurangan PT itu sendiri. Disinilah perlunya PT untuk selalu menjaga citranya dimasyarakat dan selalu memberikan informasi ke dunia luar sehingga PT tersebut dikenal oleh masyarakat.

\section{b. Keterkaitan Pemasaran Dengan Penentuan Pilihan}

Pada dasarnya proses pemasaran merupakan proses mengkomunikasikan berbagai hal yang terdapat dalam suatu lembaga kepada masyarakat luas dengan tujuan untuk menarik minat masyakrakat untuk membeli atau untuk bergabung dengan lembaga tersebut. Oleh karena itulah proses pemasaran tidak hanya dilakukan pada lembaga yang mengutamakan laba (semacam Lembaga produksi/ jasa), tetapi juga diperlukan oleh lembaga-lembaga lain yang tidak memerlukan laba (semacam, lembaga keagamaan, lembaga sosial, lembaga pendidikan). Bahkan perseoranganpun pada dewasa ini juga memerlukan pemasaran, misalnya yang dilakukan oleh politikus. Oleh karena itulah dalam melakukan pemasaran, pihak pemasaran harus melakukan sesuatu yang dapat menarik minat masyarakat. 
Untuk menimbulkan motivasi bagi masyarakat tersebut pihak pemasaran harus dapat melakukan persuasi terhadap hal-hal yang disampaikannya kepada masyarakat. Secara bahasa persuasi memiliki makna untuk membujuk atau merayu, yaitu kemampuan untuk membujuk, merayu, mempengaruhi pikiran, perasaan dan perilaku masyarakat. Tetapi dalam kaitan ini persuasi bukan hanya membujuk atau merayu semata-mata. Melainkan suatu teknik untuk mempengaruhi dengan mempergunakan data dan fakta psikologis maupun sosiologis masyarakat. Untuk itulah dalam melakukan pemasaran, hendaknya memperhatikan hal-hal sebagai berikut; a) Pesan atau ajakan yang disampaikan harus dapat menimbulkan perasaan tertentu pada masyarakat; b) Pesan atau ajakan itu hendaknya berisi lambang-lambang atau tanda-tanda yang sesuai dengan daya tangkap, daya serap, dan daya nilai sebagian masyarakat, terutama golongan masyarakat yang dituju; c) Pesan atau ajakan itu dapat membangkitkan kebutuhan dan keinginan harapan masyarakat; d) Pesan itu membangkitkan harapan ${ }^{64}$.

Setelah menerima/mengetahui dari pemasaran yang dilakukan oleh pihak pemasar tersebut diharapkan masyarakat dapat mengambil keputusan. Pengambilan keputusan ini akan lebih berhasil setelah melalui tahapan "dialog diri". Proses mencapai keputusan ini disebut inovasi optimal, yang terdiri atas lima tahapan yaitu; a) Kesadaran, masyarakat menyadari adanya ide-ide baru tetapi masih kurang informasi; b) Menaruh minat, masyarakat mulai menaruh minat terhadap inovasi dan mencari, menginginkan informasi yang lebih banyak; c) Penilaian, masyarakat mengadakan penilaian sendiri terhadap ide baru itu dihubungkan dengan situasinya saat ini dan masa mendatang, lalu menentukan keinginan untuk mencobanya atau tidak; d) Percobaan, masyarakat menerapkan ide-ide baru dalam skala kecil untuk menentukan keguanaannya apakah sesuai dengan situasi dirinya; e) Penerimaan, masyarakat akhirnya menggunakan ide baru tersebut secara tetap dengan skala luas ${ }^{65}$. Akibat banyaknya pilihan yang ada dimasyarakat (karena banyaknya lembaga yang melakukan pemasaran) maka pengambilan keputusan memiliki berbagai konsekuensi. Misanya, keputusan untuk memilih perguruan tinggi memiliki banyak konsekuensi yang harus diperhitungkan, mutu, baiya, lokasi dan sebagainya. Mungkin masyarakat akan memilih PT yang bermutu walaupun biayanya mahal, atau sebaliknya, mungkin juga akan memilih berdasarkan atas lokasi yang dekat dengan kota/ rumah/ kerabat, masih banyak kemungkinan dalam hal ini. Oleh karena itulah keputusan yang diambil harus 
benar-benar tetap dengan terlebih dahulu memperhitungkan konsekuensinya. Konsekuensi sendiri merupakan perubahan yang terjadi dalam sistem sosial sebagai hasil penerimaan atau penolakan terhadap suatu inovasi. Satu hal yang penting dalam melakukan pemasaran adalah, pihak pemasar hendaknya jujur dengan apa yang diinformasikan kepada masyarakat, karena hal ini akan dapat mempengaruhi pandangan masyarakat terhadap lembaga atau pihak pemasar tersebut.

Evans menggambarkan keterkaitan antara pengembilan keputusan dengan pemasaran dalam proses pembelian seperti terlihat pada gambar 10 :

Gambar 10: Hubungan Pengambilan Keputusan dan Pemasaran dalam Proses Pembelian ${ }^{66}$

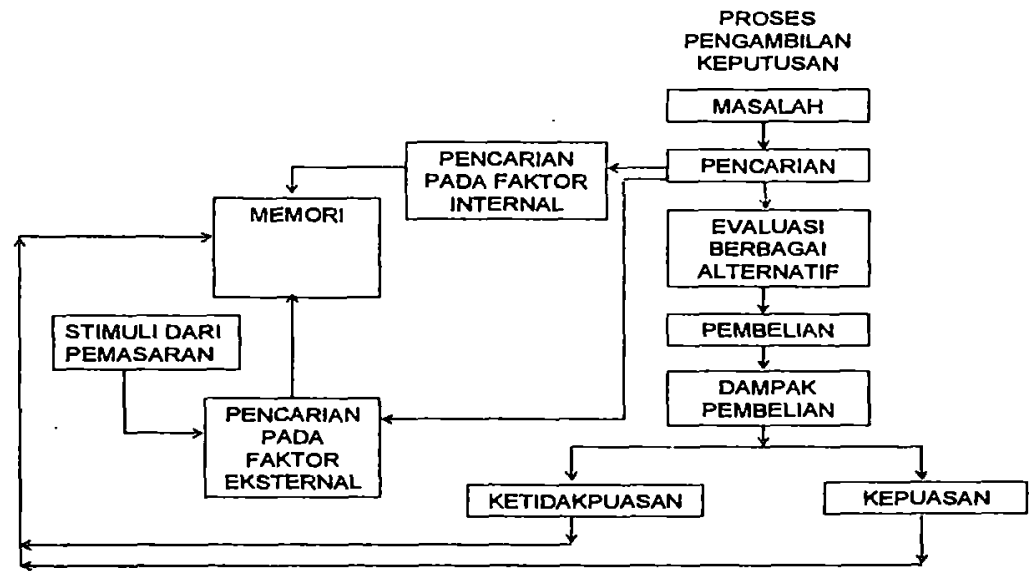

Gambar 10 mengindikasikan bahwa di dalam proses pembelian yang diawali dengan adanya masalah (sehingga memerlukan pembelian), maka pembeli akan mengadakan pencarian baik pada faktor internal (dalam diri pembeli sendiri) maupun dari faktor eksternal (di luar diri pembeli). Pencarian di dalam dilakukan jika pembeli sudah mengenal sesuatu yang akan dibeli. Pengenalan terhadap sesuatu yang akan dibeli tersebut dilakukan dari proses pembelian (pengalaman) yang sudah dialami oleh pembeli. Proses pengambilan keputusan seperti ini dilakukan melalui proses "dialog diri". Namun demikian jika didalam ingatan pembeli (memori) belum memiliki data tentang sesuatu yang akan dibelinya maka pembeli akan melakukan pencarian pada faktor eksternal. Pencarian pada faktor 
eksternal akan dipengaruhi oleh pemasaran. Baik dari pengalaman maupun dari pemasaran inilah citra sesuatu dapat dibangun yang pada akhirnya disimpan di dalam memori pembeli yang akan digunakan untuk mengmbil keputusan pada waktu yang akan datang jika mendapatkan kembali permasalahan yang hampir sama.

\section{H. Penutup}

Melihat dari kompleksitas pekerjaan pemasaran di PT tersebut, sulit rasanya bagi PT untuk mampu memenangkan persaingan jika pekerjaan pemasaran ini dilakukan sambil lalu, temporal, tidak dilakukan secara terencana dan oleh personel yang tidak kompeten. Pada PT-PT di beberapa negara memiliki bagian yang berfungsi sebagai bagian pemasaran di PT, yang biasa disebut dengan admission office. PT di Indonesia sebagai lembaga pendidikan tinggi yang memiliki otonomi dalam pengelolaan lembaga tentunya sudah saatnya untuk memiliki bagian pemasaran tersendiri. Bagian pemasaran ini merupakan suatu unit kerja yang bertanggungjawab langsung kepada Rektor, dengan tugas utama; 1) membangun, mengembangkan dan menjaga citra PT di masyarakat, 2) mengetahui kebutuhan, keinginan dan harapan pasar, 3) menentukan dan mengembangkan pasar potensial, 4) menentukan dan melakukan promosi secara tepat.

Sehingga, pekerjaan pemasaran harus dilakukan sepanjang tahun, bukan pekerjaan yang hanya dilakukan menjelang dan saat penerimaan mahasiswa baru saja. Pekerjaan pengukuran tentang selera pasar, pembentukan citra harus dilakukan sepanjang tahun dan didokumentasikan secara baik, sehingga kebijakan yang tepat tentang produk PT yang akan dihasilkan juga tepat.

\section{Endnotes}

1 Upload. 2005. Penerimaan Mahasiswa Baru ITS Meningkat. Surabaya+ ITS

2 Tampubolon, Daulat P. 2000. Perguruan Tinggi Bermutu: Paradigma Baru. Manajemen Pendidikan Tinggi Menghadapi Tantangan Abad 21. Jakarta: Gramedia.

3 Higher Education Long Term Srategy 2003-2010. 2003. Jakarta: Dirjen Dikti. Hal 1012

Ulul Albab, Vol. 6 No. 1, 2005 
4 Kriegbaum, Richard A. 1981. Marketing to Advance the Small College. Dalam Wilmer, Wesley K (Ed). Advancing the Small college (hlm 35 -46) San Fransisco: JosseyBass Inc.

5 Rahmat, Jalaludin. 1988. Psikologi Komunikasi. Jakarta: Gramedia

6 Kotler, Philips \& Andreasen. 1987. Strategi Pemasaran Untuk Organisasi Nir-Laba. Terjemahan oleh Emilia, Ova \& Hasanbasri Mubasyir, 1996. Yogyakarta: Gadjah Mada University Press.

7 Stanton, 1984. Prinsip Pemasaran. Terjemahan oleh Sundaru, Sadu \& Hutauruk, Gunawan. 1993. Jakarta: Erlangga

8 Kotler, Philips. 1984. Fundamental of Marketing. Englewood Cliffs: Prentice Hall

9 Tampubolon, Daulat P. Op.Cit

10 Ibid

11 Stanton, Op.Cit

12 Drucker, Peter F. 1990. Managing the Non-Profit Organization New York: Harper Business.

13 Stanton, Op.Cit

14 Drucker, Peter F. Op.Cit

15 Kotler, Philips. Op.Cit

16 Stanton. Op.Cit

17 Evans, Ian G. 1995. Marketing for Schools: London: Cassell

18 Pulungan, Ismail. 2001. Manajemen Mutu Terpadu. Jakarta: Dirjen Dikti Diknas.

19 Unal, Omer Farukh. 2004. Application of Total Quality Management in Higher Education. Azerbaijan: Qafqaz University (online). (http://www.qafqaz.edu.az-journal)

20 Sallis Edward. 1993. Total Quality Management in Education. London: Kogan Page Educational Management Series

21 Supriyanto, Akhmad. 1999. Total Quality Management (TQM) di Bidang Pendidikan. Malang: FIP Universitas Negeri Malang

22 Kotler. Op.Cit. Lihat juga, Evans. Op.Cit

23 Kotler. Ibid

24 Kriegbaum, Richard A. Op. Cit

25 Evans, Ian G. Op.Cit

26 Kriegbaum, RichardA. Op. Cit

27 Clungstone, R. Wayne. 1981. Advancing Through the Looking Glass: A Servant Leadership Perspective for Small College, dalam Wilmer Wesley K (Ed). Advancing The Small College (hlm. 5-20). San Fransisco: Jossey-Bass Publisher 
28 Topor, Bob. 1998. Institutional Image Assesment. Topor Consulting Group Intl. (www.)

29 Kertajaya, Hermawan. 1996. Pembentukan image. Makalah: tidak diterbitkan

30 Topor, Bob. Op.Cit

31 Ibid

32 Moll, Richard. 1979. Playing The Private College Admissions Game. Harmodsworth: Penguin Books. Ltd.

33 Drucker, Peter F. Op.Cit

34 Kriegbaum, Richard A. Op. Cit

35 Moll, Richard. Op. Cit

36 Kotler. Op.Cit. lihat juga. Drucker, Peter F. Op. Cit

37 Kotler, Philips \& Andreasen. Op.Cit

38 Kotler, Philip \& Murphy, Patrick E. 1986. Strategic Planning for Higher Education Dalam Peterson, Marvin W (Ed). Organization And Govermance in Higher Education. (hlm. 428 - 444) Lexington Massachusetts: Ginn Press.

39 Moll, Richard. Op. Cit

40 Kotler, Philips \& Andreasen. Op.Cit

41 Evans, Ian G. Op.Cit

42 Fram, Eugene H. 1973. Marketing Higher Education. Dalam Vermilye, Dykman W (Ed). The Future in The Making. (hlm. 56 - 69). San Fransisco: Jossey-Bass Inc.

43 Alma, Buchari, 1992. Manajemen Pemasaran dan Pemasaran Jasa, Bandung: Alfabeta.

44 Kertajaya, Hermawan. Op.Cit

45 Ibid

46 Moll, Richard. Op. Cit

47 Ibid

48 Kotler, Philips \& Andreasen. Op.Cit

49 Drucker, Peter F. Op.Cit

50 Alma, Buchari, Op.Cit

51 Kotler, Philips \& Andreasen. Op.Cit

52 Kriegbaum, Richard A. Op. Cit

53 Alma, Buchari, Op.Cit

54 Ibid

55 Ibid

56 Kotler, Philips \& Andreasen. Op.Cit

Ulul Albab, Vol. 6 No. 1, 2005 
57 Rahmat, Jalaludin. 1988. Psikologi Komunikasi. Jakarta: Gramedia

58 Ibid

59 Ibid

60 Alma, Buchari. Op.Cit

61 Ibid

62 Kotler, Philips \& Andreasen. Op.Cit

63 Ibid

64 Rahmad, Jalaludin. Op.Cit

65 Siahaan, SM. 1990. Komunikasi Pemahaman dan Penerapannya. Jakarta: PT BPK Gunung Mulia

66 Evans, Ian G. Op.Cit

\section{Daftar Pustaka}

Alma, Buchari, 1992. Manajemen Pemasaran dan Pemasaran Jasa, Bandung: Alfabeta.

Clungstone, R. Wayne. 1981. Advancing Through the Looking Glass: A Servant Leadership Perspective for Small College, dalam Wilmer Wesley K (Ed). Advancing The Small College (hlm. 5 - 20). San Fransisco: Jossey-Bass Publisher

Drucker, Peter F. 1990. Managing the Non-Profit Organization New York: Harper Business.

Evans, Ian G. 1995. Marketing for Schools. London: Cassell

Fram, Eugene H. 1973. Marketing Higher Education. Dalam Vermilye, Dykman W (Ed). The Future in The Making. (hlm. 56-69). San Fransisco: JosseyBass Inc.

Higher Education Long Term Srategy 2003-2010. 2003. Jakarta: Dirjen Dikti. Hal 10-12

Industri Pendidikan. 1995, 27 Mei. Gatra. Hlm. 23 - 29

Kertajaya. 1996. Pembentukan image. Makalah: tidak diterbitkan

Kotler, Philips. 1984. Fundamental of Marketing. Englewood Cliffs: Prentice Hall 
Kotler, Philips \& Andreasen. 1987. Strategi Pemasaran Untuk Organisasi NirLaba. Terjemahan oleh Emilia, Ova \& Hasanbasri Mubasyir, 1996. Yogyakarta: Gadjah Mada University Press.

Kotler, Philip \& Murphy, Patrick E. 1986. Strategic Planning for Higher Education Dalam Peterson, Marvin W (Ed). Organization And Govermance in Higher Education. (hlm. 428 - 444) Lexington Massachusetts: Ginn Press. riegbaum, Richard A. 1981. Marketing to Advance the Small College. Dalam Wilmer, Wesley K (Ed). Advancing the Small college (hlm 35 -46) San Fransisco: Jossey-Bass Inc.

Moll, Richard. 1979. Playing The Private College Admissions Game. Harmodsworth: Penguin Books. Ltd.

Peraturan Pemerintah No. 60 Tahun 1999 tentang Pendidikan Tinggi

Pulungan, Ismail. 2001. Manajemen Mutu Terpadu . Jakarta: Dirjen Dikti Diknas. Rahmat, Jalaludin. 1988. Psikologi Komumikasi. Jakarta: Gramedia

Sallis Edward. 1993. Total Quality Management in Education. London: Kogan Page Educational Management Series

Siahaan, SM. 1990. Komunikasi Pemahaman dan Penerapannya. Jakarta: PT BPK Gunung Mulia

Stanton, 1984. Prinsip Pemasaran. Terjemahan oleh Sundaru, Sadu \& Hutauruk, Gunawan: 1993.Jakarta: Erlangga

Supriyanto, Akhmad. 1999. Total Quality Management (TQM) di Bidang Pendidikan. Malang: FIP Universitas Negeri Malang

Tampubolon, Daulat P. 2000. Perguruan Tinggi Bermutu: Paradigma Baru Manajemen Pendidikan Tinggi Menghadapi Tantangan Abad 21. Jakarta: Gramedia.

Topor, Bob. 1998. Institutional Image Assesment. Topor Consulting Group Intl. (www.marketinged.com/library/article/imagehowto.html) online

Unal, Omer Farukh. 2004. Application of Total Quality Management in Higher Education. Azerbaijan: Qafqaz University (online). (http:// www.qafqaz.edu.az-journal )

Upload. 2005. Penerimaan Mahasiswa Baru ITS Meningkat, Surabaya: ITS 